\title{
COMPETITIVENESS OF GEORGIA AND POLAND IN AGRI-FOOD EXPORTS IN THE EU MARKET: A COMPARATIVE ANALYSIS
}

\section{ŁUKASZ AMBROZIAK}

PhD, Institute of Agriculture and Food

Economics - National Research Institute

Lukasz.Ambroziak@ierigz.waw.pl https://doi.org/10.35945/gb.2018.05.005

\section{KEYWORDS: COMPETITIVE POSITION IN EXPORTS, AGRI-FOOD PRODUCTS, POLAND, GEORGIA, THE EUROPEAN UNION}

\section{INTRODUCTION}

On 27 June 2014, the EU signed an association agreement with Georgia. It came into force in full on 1 July 2016, but the most important and the most comprehensive part of the agreement, namely, the agreement on a deepand comprehensive free trade area (DCFTA), was, in most cases, provisionally applied since September 2014. Thanks to this agreement, Georgia obtained duty-free access to the large EU market. The condition was only to meet the norms and standards of exported goods, which in the case of agri-food products focused mainly on sanitary and phyto sanitary measures (Bułkowska, 2017).

The process of liberalising trade between Poland and the European Communities was launched in 1992. Back then, the part of the association agreement concerning trade liberalisation entered into force. The association agreement, called the Europe Agreement, entered into force a bit later,as in 1994. Agri-food products were subject to gradual liberalisation due to their high sensitivity. Duty-free access to the EU market was obtained by Poland in 2004 at the time of accession to the European Union. Also in this case, in order to be able to sell agri-food products in the single European market, Polish producers had to meet a number of norms and standards.

From the viewpoint of the theory of international trade (including the conclusions on the use of the gravity model in trade), Poland and Georgia differ in terms of many characteristics. These are, inter alia (Geostat, 2018; CSO, 2017):

- Size of the economy - in 2016, Georgia's Gross Domestic Product according to purchasing power parity accounted for $3 \%$ of Poland's GDP;

- Population - in 2016, the population of Georgia represented $10 \%$ of the population in Poland (3.7 million and 38.0 million, respectively);

- Level of income of the population - in 2016, Georgia's GDPper capita according to PPP amounted to $36 \%$ of the level recorded in Poland (USD 9.3 and 25.7 thousand per capita, respectively);

- Agricultural area - in 2016, it amounted to 2.6 million ha in Georgia, while in Poland it exceeded 14 million ha;

- global output of agriculture - in 2016, its value in Georgia was 16 times lower than in Poland.
In addition, the geographical distance between Georgia and the EU countries is much greater that between Poland and the EU countries. According to the gravity model, the greater is the distance between countries, and thus the transaction costs, the less intense is trade between them. This is particularly important for agri-food products that are less durable than industrial products.

The statistics presented above relating to the selected characteristics clearly indicate differences in the development potential of trade in agri-food products and in particular the export from Georgia to the EU. This is reflected in the competitive position of Georgia on the EU markets. The objective of the article is therefore to assess the competitive position of Georgia and, for comparison, also that of Poland, in the export of agri-food products to the EU. The main study question is: do Georgian and Polish food producers compete in the EU market in the same product groups?

\section{Selected theoretical aspects of a competitiveness}

The term competitiveness has been widely used and discussed in the literature. In the literature there are a lot of definitions of the competitiveness (e.g. Krugman 1981; Aiginger et al. 2013; Peneder 2001; Farole et al. 2010). It results from the fact that individual authors pay attention to the different aspects of competitiveness and analyse it at different levels. According to the definition of the Organization for Economic Co-operation and Development (OECD 2016), 'competitiveness is a measure of a country's advantage or disadvantage in selling its products in international markets'. Similar definition was adopted by the Institute of Agricultural and Food Economics - National Research Institute (IAFE-NRI) for the purpose of the studies on international competitiveness of the Polish food sector. According IAFENRI, 'food manufacturers' competitiveness is the ability of domestic producers to place their products in foreign markets - both in the EU and in third country markets - and the ability to developed effective exports' (Szczepaniak 2014).

Sometimes the term competitiveness is understood broader as a 'competitiveness system' (Szczepaniak 2014, p.17). It consists of four elements: competitive potential, competitive strategy, competitive instruments and the competitive position. Generally, it can be stated that the 
competitive potential held by a given company determines adopting a specific competitive strategy. This strategy creates a base for selecting specific instruments of competition, which in turn helps to achieve a specific competitive position (Szczepaniak 2014, p. 16). Thus, the competitive position can be considered as an indicator of competitiveness. According to Misala (2005, p. 300), the competitive position means condition and changes in shares of the given country in the widely understood international turnover, i.e. in international trade in goods and services, and in international movements of production factors as well as the evolution of the structure of these movements. To evaluate the competitive position, many indicators are used, which allow to evaluate the results of foreign trade in the past. Two of them, i.e. the trade coverage index (TC) and the Balassa revealed comparative advantages index (RCA) are used in this research study.

\section{Research method and materials}

For the purpose of the paper, twoindicators of the competitive position of Georgia and Poland in exports of agrifood products were employed, namely trade coverage index (TC) and Balassa's revealed comparative advantages index (RCA).

TC index was calculated according to the formula:

$$
T C_{i j}=\frac{X_{i j}}{Y_{i j}}
$$

where:

$\mathrm{TC}_{\mathrm{j} j}$ - trade coverage index in trade in the $\mathrm{i}^{\text {th }}$ product group of the $\mathrm{j}^{\text {th }}$ country with the EU,

$\mathrm{X}_{\mathrm{ij}}$ - exports of the $\mathrm{i}^{\text {th }}$ product group (here: agri-food products in total and by HS chapters) of the $\mathrm{j}^{\text {th }}$ country to the EU,

$\mathrm{M}_{\mathrm{ij}}$ - imports of the $\mathrm{i}^{\text {th }}$ product group (here: agri-food products in total and by HS chapters) of the $\mathrm{j}^{\text {th }}$ country from the EU.

TC index determines the extent to which expenses on imported goods are covered by the revenue from their exports. The TC index is used to study the relationship between the exports and the imports at the level of entire trade, sector or product. The TC index greater than 1 means that the export value exceeds the import value, thus the given country has the relative competitive advantage over partners.

Revealed comparative advantages indices were calculated according to the formula:

$$
R C A_{i j}=\frac{X_{i j}}{\sum_{i=1}^{N} X_{i j}}: \frac{X_{i w}}{\sum_{i=1}^{N} X_{i w}}
$$

where:

$\mathrm{RCA}_{\mathrm{ij}}$ - revealed comparative advantage indexin the $\mathrm{j}^{\text {th }}$ country exports of the $\mathrm{i}^{\text {th }}$ product group to the EU,

$\mathrm{X}_{\mathrm{ij}}$ - the $\mathrm{j}^{\text {th }}$ country exports of the $\mathrm{i}^{\text {th }}$ product group (here: agri-food products in total and by HS chapters) to the EU,
$X^{\text {iw }}$ - world exports of the $\mathrm{i}^{\text {th }}$ product group to the EU,

$\mathrm{N}$ - number of product groups (here: total exports).

The essence of the RCA index is to determine whether the share of a given commodity group in the exports of a given country is higher/lower than the share of this commodity group in the world exports to the specific market. When the index is greater than 1 (the share of the given commodity group in the exports of a country is higher than the respective share in the world export) - a given country has revealed comparative advantage in the exports to the specific market. Otherwise, when the index is lower than 1 (the share of the given commodity group in the exports of the country in question is lower than the share of this product group in the world exports) - the analysed country does not have revealed comparative advantages in the exports to the specific market.

The study is based on the trade data from the World Integrated Trade Solution (WITS) database (Comtrade, HS - Harmonised System 2002), expressed in USD. Agri-food products are understood as products classified in chapters 01-24 of the Harmonised Commodity Description and Coding System (HS).

\section{Research results \\ Agri-food trade of Georgia and Poland with the EU}

The value of the export of agri-food products from Georgia to the European Union in 2016 was USD 221 million and the value of the import was 222 USD million. This meant, when compared to 2004, an increase by more than 6 times in the export value and nearly 5 times in the import value. In the analysed period, Georgia had a permanently negative EU food trade balance, although in 2016 the trade balance equilibrium was almost achieved. In turn, the export value ofagri-food products from Poland to the EU in 2016 was USD20.5 billion and the import value was USD 12.0 billion. In the years 2004-2016, the export value of Polish food to the EU market increased more than 4 times, and the import value $-3,5$ times. Thus, during the Polish membership in the $\mathrm{EU}$, the surplus of trade in agri-food products was growing steadily. In 2016, its value exceeded EUR 8 billion.

The comparison shows that the value of the Georgian food export to the EU represented only about $1 \%$ of the Polish food export. This share was lower than in the case of comparing GDP of both countries. This was due to the fact for Georgia the EU was not the dominant outlet market for Georgia, just as it was for Poland. In 2016, only $32 \%$ of the Georgian food exportwent to the EU market (by 15 percentage points more than in 2004), while the analogous ratio for Poland was more than $80 \%$. Despite a clear reduction, still nearly half of Georgian agri-food products sold abroad found buyers in the Commonwealth of Independent States. The share of the EU countries in the agri-food import of Georgia and Poland was lower than in the export and in 2016 amounted to, respectively, $21 \%$ and $68 \%$.

The commercial structure of the Georgianagri-food 
export to the EU has been heavily concentrated on two HS sections, i.e. fruit and nuts (HS 08) and beverages (HS 22). In the years 2004-2016, the importance of products fromthe former increased significantly (from $37 \%$ in 2004 to $66 \%$ in 2016) and from the latter decreased (from $45 \%$ to $23 \%$ ). In total, fruit and nuts as well as beverages 2016 accounted for nearly $90 \%$ of the Georgian agri-food export to the EU. The rest was, inter alia, fruit and vegetable products, products of the milling industry, malt and starches and vegetables. The strong concentration in the Georgian agri-foodexporton several product groups only reflects the limited possibilities of the development potential of the agricultural production and food processing on the supply side.

The commodity structure of the Polish agri-food export to the EU was more diversified. Three main HS sections, i.e. meat and offal, tobacco and tobacco products and cereals and pastry accounted for $35 \%$ of the Polish exportvalue to the Union market. Of great importance were also dairy products, fish and seafood, meat and fish products, chocolate products and various food products.

The commercial structures of the Georgian and Polish import from the EU were more diversified than their commercial structures in the export and showed some similarities. Meat and offal, dairy products, chocolate products, cereals and pastry, various food products were important in the import of both countries. Moreover, in the Georgian import the significantly higher share than in the Polish import was that of beverages, sugars and confectionery. The reverse situation was in the case ofvegetables and fruit their importance in the polish import was higher than in the Georgian import from the EU.

\section{Competitive position in agri-food export of Georgia and Poland in the EU market}

In the years 2004-2016, the trade coverage indicesinPolish trade in agri-food products (total) with the EU were permanently higher than the corresponding indices in Georgian. This meant that in Poland, revenues from the food export to the EU covered expenses for the food import from EU to the greater extent than in Georgia. In Georgia in only two years i.e. 2005 and 2007 the export exceeded the import. Despite the improvement in the TC indices observed since 2008, Georgia still failed to obtain a surplus in foreign food trade with the EU (in 2016, the TC index was 0.99).

The reverse situation was related to the RCA index. In the analysed period, its value in the Georgian agri-food export to the EU was sometimes even several times higher than in the case of Poland. Both analysed countries had revealed comparative advantages in the agri-food export to the EU, with the clearly stronger advantage of Georgia. The highest value of the RCA index in the Georgian food export to the EU market was recorded in 2007 (RCA $>5$ ). In 2008, the value of the RCA index decreased to the value just below 2, which resulted from hostilities in the area of Georgia. Since 2008, the comparative advantages of Georgian food exporters in the EU market have been strengthening again. In 2016, the share of agri-food products in the Georgianexport to the EU was nearly four times higher than in the global export to these countries.

In the years 2004-2006, Georgia had the TC indiceshigher than 1 in trade with the EU inproducts of five HS sections, i.e. fruit and nuts, coffee, tea and spices, beverages, oilseeds

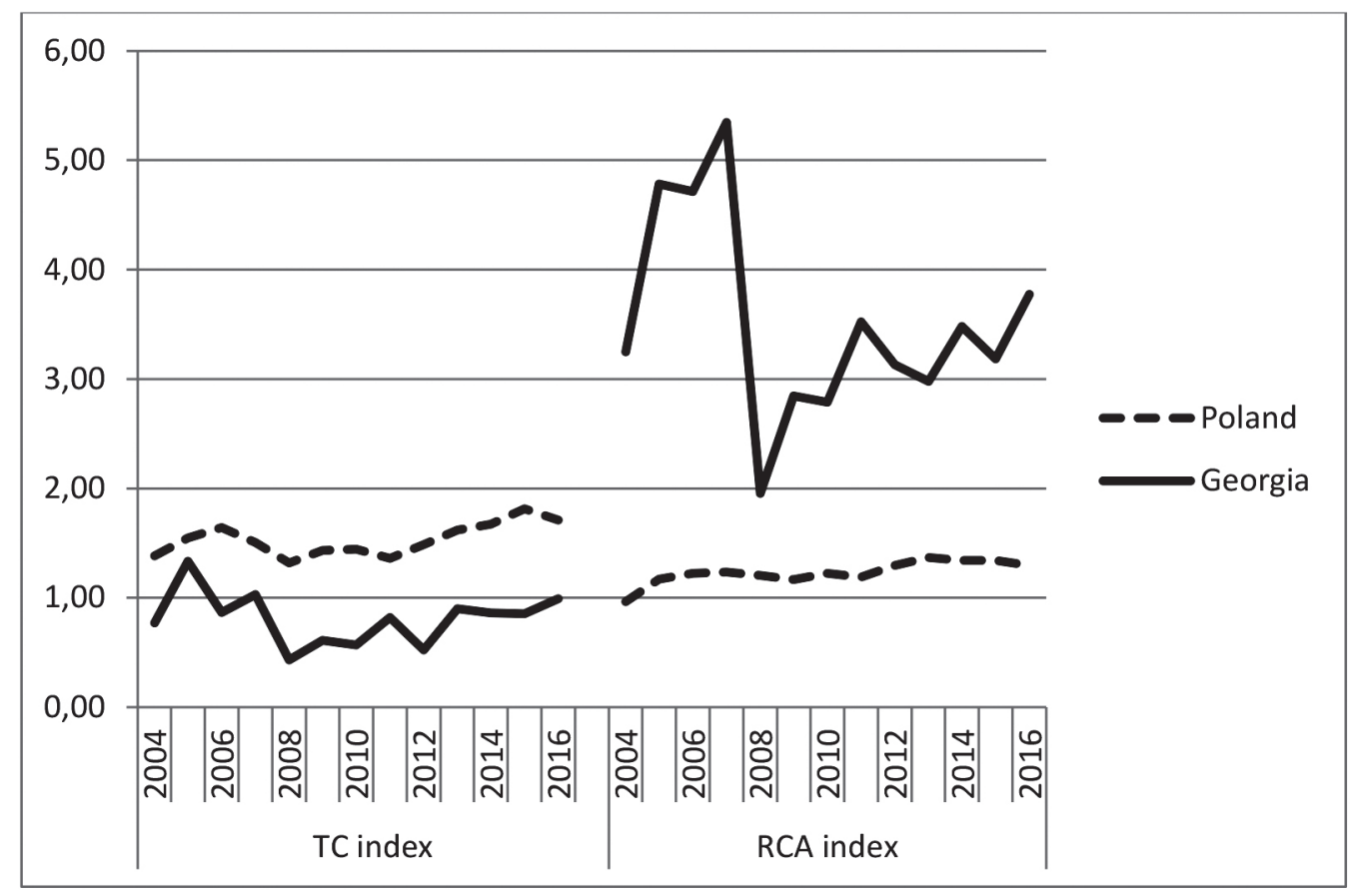

Fig. 1: TC and RCA indices in agri-food exportof Georgia and Poland to the EU Source: Own calculations based on WITS-Comtrade (2018) 
Table 1. TC and RCA indices in agri-food export of Georgia and Poland to the EU by HS division

\begin{tabular}{|c|c|c|c|c|c|c|c|c|c|}
\hline \multirow{3}{*}{$\begin{array}{l}\text { HS } \\
\text { code }\end{array}$} & \multirow{3}{*}{ Description } & \multicolumn{4}{|c|}{ TC index } & \multicolumn{4}{|c|}{ RCA index } \\
\hline & & \multicolumn{2}{|c|}{ Georgia } & \multicolumn{2}{|c|}{ Poland } & \multicolumn{2}{|c|}{ Georgia } & \multicolumn{2}{|c|}{ Poland } \\
\hline & & $\begin{array}{l}2004- \\
2006\end{array}$ & $\begin{array}{l}2014- \\
2016\end{array}$ & $\begin{array}{l}2004- \\
2006\end{array}$ & $\begin{array}{l}2014- \\
2016\end{array}$ & $\begin{array}{l}2004- \\
2006\end{array}$ & $\begin{array}{l}2014- \\
2016\end{array}$ & $\begin{array}{l}2004- \\
2006\end{array}$ & $\begin{array}{l}2014- \\
2016\end{array}$ \\
\hline 01 & Live animals & 0.00 & 0.00 & 2.91 & 0.18 & 0.00 & 0.00 & 2.41 & 0.40 \\
\hline 02 & Meat and edible meat offal & 0.00 & 0.00 & 2.54 & 2.29 & 0.00 & 0.02 & 1.76 & 2.74 \\
\hline 03 & Fish and seafood & 0.01 & 0.00 & 3.22 & 2.57 & 0.01 & 0.00 & 0.91 & 1.05 \\
\hline 04 & Dairy produce & 0.17 & 0.00 & 5.93 & 1.78 & 0.89 & 0.01 & 1.67 & 1.38 \\
\hline 05 & Products of animal origin n.e.s. & 0.00 & 0.00 & 1.51 & 1.27 & 0.00 & 0.02 & 2.58 & 1.83 \\
\hline 06 & Live trees and other plants & 0.10 & 0.13 & 0.42 & 0.34 & 0.17 & 0.29 & 0.37 & 0.23 \\
\hline 07 & Vegetables & 0.23 & 0.31 & 2.36 & 1.44 & 0.07 & 0.26 & 1.64 & 1.12 \\
\hline 08 & Fruit and nuts & 358.00 & 24.01 & 1.05 & 0.95 & 31.02 & 29.47 & 0.95 & 0.58 \\
\hline 09 & Coffee, tea and spices & 1.27 & 0.11 & 0.86 & 2.10 & 1.92 & 0.15 & 0.43 & 0.98 \\
\hline 10 & Cereals & 0.00 & 0.00 & 0.54 & 2.44 & 0.00 & 0.00 & 0.48 & 1.12 \\
\hline 11 & Products of the milling industry & 0.08 & 0.50 & 0.12 & 0.62 & 3.53 & 8.83 & 0.36 & 0.99 \\
\hline 12 & Oil seeds and oleaginous fruits & 1.05 & 0.61 & 0.95 & 1.55 & 1.80 & 0.78 & 0.61 & 0.70 \\
\hline 13 & Vegetables saps and extracts & 0.02 & 0.95 & 0.06 & 0.08 & 0.12 & 1.92 & 0.12 & 0.09 \\
\hline 14 & Vegetable products n.e.s. & 2.40 & 0.79 & 5.75 & 0.64 & 0.58 & 0.72 & 1.32 & 0.21 \\
\hline 15 & Animal or vegetable fats and oils & 0.01 & 0.22 & 0.42 & 0.86 & 0.04 & 0.32 & 0.46 & 0.80 \\
\hline 16 & Preparations of meat and fish & 0.00 & 0.00 & 4.88 & 5.91 & 0.00 & 0.00 & 1.38 & 2.11 \\
\hline 17 & Sugars and sugar confectionery & 0.07 & 0.00 & 1.52 & 1.32 & 0.70 & 0.00 & 1.48 & 1.35 \\
\hline 18 & Cocoa and cocoa preparations & 0.10 & 0.00 & 1.03 & 1.31 & 0.63 & 0.00 & 1.20 & 1.64 \\
\hline 19 & $\begin{array}{l}\text { Preparations of cereals and } \\
\text { pastrycooks' products }\end{array}$ & 0.01 & 0.00 & 1.88 & 2.11 & 0.03 & 0.00 & 1.47 & 1.82 \\
\hline 20 & $\begin{array}{l}\text { Preparations of vegetables and } \\
\text { fruits }\end{array}$ & 0.95 & 1.24 & 3.42 & 2.34 & 3.96 & 3.47 & 1.74 & 1.20 \\
\hline 21 & Miscellaneous edible preparations & 0.14 & 0.06 & 0.89 & 1.69 & 0.70 & 0.30 & 1.51 & 1.85 \\
\hline 22 & Beverages and spirits & 1.91 & 1.13 & 0.84 & 1.02 & 16.21 & 9.63 & 0.39 & 0.51 \\
\hline 23 & $\begin{array}{l}\text { Residues and prepared animal } \\
\text { fodder }\end{array}$ & 0.00 & 0.00 & 0.54 & 1.17 & 0.00 & 0.00 & 0.57 & 0.73 \\
\hline 24 & Tobacco and tobacco products & 0.00 & 0.03 & 1.63 & 5.94 & 0.03 & 0.13 & 0.74 & 4.66 \\
\hline & Agri-food products & 0.99 & 0.90 & 1.54 & 1.73 & 4.39 & 3.47 & 2.30 & 3.28 \\
\hline
\end{tabular}

Source: Own calculations based on WITS-Comtrade (2018)

and oleaginous fruit and other products of plant origin. In the analysed period in three product groups, i.e. coffee, tea and spices, oilseeds and oleaginous fruit and other products of plant origin the TC indices decreased to the level below 1. The surplus has, however, been achieved in trade with the EU infruit and vegetable products. In the years 2004-2016, Georgia had a surplus in trade with the EU in products of three HS sections, i.e. fruit and nuts, fruit and nut products and beverages. These products accounted for as much as $95 \%$ of the Georgian food export to the EU.

\section{Georgia}

In the years 2004-2006, Georgia had the revealed comparative advantages $(R C A>1)$ in the export to the EU of products of six HS sections. These were: fruit and nuts, beverages, fruit and vegetable products, products of the milling industry, malt and starches, oilseeds and oleaginous fruit, and coffee, tea and spices. The particularly high RCA indices were recorded in the export of the first two groups (31.0 and 16.2, respectively). This meant that the share of fruit and nuts in the Georgian export to the EU was in the years 2004-2006 as many as 31 times higher than the share of those products in the global export to the Union market. In the case of fruit and vegetable products, the analogous shares differed by more than sixteen times. In the analysed period, Georgia lost the revealed comparative advantages it held in the years 2004-2006 in theexportto the UE of coffee, tea and spices as well as oilseeds and oleaginous fruit while obtained the advantages in the export of plant extracts. In the years 
2014-2016, Georgian producers had the revealed comparative advantages in the EU market in exporting products of five HS sections. These were: fruit and nuts, beverages, products of the milling industry, malt and starches, fruit and vegetable products and plant extracts. Still, very high was the RCA index in the export of fruit and nuts - it amounted to 29.5. When compared to the beginning of the analysed period, the RCA index in the Georgian export of beverages to the EU clearly declined, but still remained very high in the years 2014-2016 (9.63). The share of products of the milling industry, malt and starch in the Georgian export to the EU was nearly 9 times higher than in the global export of these products to this market, the share of fruit and vegetable products $-3,5$ times and that of plant extracts nearly twice.

The high RCA indices in the Georgian export to the EU of fruit and nuts, beverages and fruit and vegetable products are the result of the strong concentration of export on only several products and product groups. These were: hazelnuts (in 2016, they accounted for $66 \%$ of the Georgian food export to the EU), spirits, including vodka, chacha and whisky (9.6\%), wine $(5.9 \%)$, mineral and carbonated water, including Borjomi (5.5\%), nut mixes for retail sale $(4 \%)$.

\section{Poland}

In the years 2004-2016, Poland had the TC indices higher than 1 in the export of products of fourteen HS sections, which accounted for $82 \%$ of the Polish food export to the EU market. During the period of EU membership, the TC indices decreased to the level of below 1 in trade in such groups of products as: live animals, fruit and nuts, and other products of plant origin. At the same time, Poland managed to achieve a surplus in trade with the EU inagri-food products such as coffee, tea and spices, cereals, oilseeds and oleaginous fruit, other food products, beverages and residues and prepared animal fodder. In the years 2014-2016, the TC indices above 1 were characteristic of trade of Poland with the EU in products of as many as eighteen groups, which accounted for nearly $92 \%$ of the Polish food export to the EU market. The highest TC indices, i.e. the largest relative export advantage over theimport has been recorded in trade in such groups of products as tobacco and tobacco products, meat and fish products, fish and seafood, fruit and vegetable products, cereals, meat and offal, coffee, tea and spices as well as cereals and pastry products.

In the years 2004-2006, Poland had the RCA indiceshigher than 1 (revealed comparative advantages) in the export to the EU of products of twelve HS sections. They accounted for $72 \%$ of the Polish food export to the EU market. During the period of EU membership, Poland lost its revealed comparative advantages in the export to the EU of two product groups, i.e. live animals and other products of plant origin. However, Polish food producers managed to achieve revealed comparative advantages in the EU market in the export of products of three HS sections. These were: fish and seafood, cereals and tobacco and tobacco products. In the years 2014-2016, Poland had the strongest comparative advantages in the EU market in the export of such product groups as tobacco and tobacco products, meat and offal, meat and fish products. The strong comparative advantages in the EU market (RCA $>1.50)$ have been recorded in the export of chocolate products, various food products and other products of animal origin.

\section{CONCLUSION}

The study has shown that, with the exception of fruit and vegetable products, Georgian and Polish food producers had the revealed comparative advantages $(R C A>1)$ in other product groups (according to HS sections) in the years 20142016. This meant that they did not compete with the same products in the EU market, and the offers of Polish and Georgian producers complemented each other. In the case of fruit and vegetable products, the revealed comparative advantage in the EU market was, in fact, held by both Georgia and Poland. However,more detailed analysis of the commercial structure of this section showed that both countries exported different products. Poland exported, inter alia, fruit juices and concentrates, frozen chips and processed or preserved champignons, while Georgia mostly nut mixes for retail sale.

In comparing the competitive position of Georgia and Poland in the export ofagri-food products to the EU, it is necessary to bear in mind the different potential of these countries in the field of the agricultural production and development of the food industry. The agricultural area in Georgia was more than five times smaller than in Poland (where most utilised agricultural areas were meadows and pastures). The global production of agriculture in Georgia was 16 times lower than in Poland. Moreover, in comparison with Poland, Georgia did not benefit from EU funds for the modernisation and restructuring of farms and food industry establishments. The inflow of foreign capital in a form of foreign direct investment was also negligible.

The Agreement on a deep and comprehensive free trade area (DCFTA) between the EU and Georgia, which entered into force since September 2014, allowed Georgia to obtain duty-free access to the large EU market. This is undoubtedly a major facility for Georgian food producers. As a prerequisite to obtain access to the EU market, it will still be necessary to meet the norms and standards of exported goods which, in the case of agri-food products, concentrated mainly on sanitary and phytosanitary measures. The association agreement provides for mechanisms which are to assist Georgian producers in adapting to the EU standards. 


\section{REFERENCES:}

AA (2014).Association Agreement between the European Union and the European Atomic Energy Community and their Member States, of the one part, and Georgia, of the other part.L261/4 (30.08.2014).

Adarov, A. \&Havlik P. (2016).Benefits and Costs of DCFTA: Evaluation of the Impact on Georgia, Moldova and Ukraine. Vienna: The Vienna Institute for International Economic Studies.

Aiginger, K. \&Bärenthaler-Sieber, S. \& Vogel, J. (2013).Competitiveness under New Perspectives.WWWforEurope Working Paper, no 44.

Bułkowska, M. (2017), Umowy o wolnym handlu UE z Ukraina, Gruzją i Mołdawią a konkurencyjność polskich producentów żywności. In I. Szczepaniak (Ed.),

Konkurencyjność polskich producentów żywności i jej determinanty (3) (pp. 107-131). Warszawa: IERiGŻ-PIB.

Farole, T. \& Reis, J.G. \& Wagle S. (2010). Analyzing Trade Competitiveness - A Diagnostics Approach.Washington DC: The World Bank. GeoStat (2018).National Statistics Office of Georgia, http://www.geostat.ge [20.04.2018].

GUS (2017).Rolnictwo w 2016 r. Warszawa: Central Statistical Office.

Krugman, P. (1981). Intra-industry Specialization and the Gains from Trade.Journal of Political Economy, no. 89.

Misala, J. (2005). Wymiana międzynarodowa i gospodarka światowa. Teoria i mechanizmyfunkcjonowania. Warsaw: SGH.

OECD (2016), Glossary of Statistical Terms, https://stats.oecd.org/glossary/detail.asp?ID=399 [9.09.2016].

Peneder, M. (2001).Entrepreneurial Competition and Industrial Location.Cheltenham: Edward Elgar.

Szczepaniak, I. Ed. (2014).Assessment of the competitiveness of Polish food producers in the European."Multi-Annual Programme 2011-2014", No 126.1, Warsaw: IAFE-NRI.

WITS-Comtrade (2018).World Integrated Trade Solutions.Comtrade database. 


\section{COMPETITIVENESS OF GEORGIA AND POLAND IN AGRI-FOOD EXPORTS IN THE EU MARKET: A COMPARATIVE ANALYSIS}

\section{ŁUKASZ AMBROZIAK}

https://doi.org/10.35945/gb.2018.05.005

$\mathrm{PhD}$, Institute of Agriculture and Food

Economics - National Research Institute

Lukasz.Ambroziak@ierigz.waw.pl

\section{KEYWORDS: COMPETITIVE POSITION IN EXPORTS, AGRI-FOOD PRODUCTS, POLAND, GEORGIA,}

\section{THE EUROPEAN UNION}

\section{SUMMARY}

The aim of the paper is a comparative analysis of a competitive position of Georgia and Poland in their agri-food exports in the EU market. This topic is especially important in the context of the Deep and Comprehensive Free Trade Agreement between EU and Georgia, which came into force in September 2014. The research question is: Do Georgia and Poland compete in the same product groups in the EU?
To answer this question some indices of the competitive position will be used: trade balance, trade coverage index and revealed comparative advantages index by Balassa. Trade data will be downloaded from UN Comtrade database. The initial research results show that Georgia and Poland significantly differ in their competitive position in agri-food exports in the EU market. However, Georgia has a large potential to increase its exports to the UE. 